\title{
Analisis Dampak Pandemi Covid-19 Terhadap Perekonomian Provinsi Sumatera Selatan
}

\author{
Ahmad Khoirudin \\ Dosen Institut Agama Islam (IAI) Al-Azhaar Lubuklinggau
}

\begin{abstract}
Abstrak
Covid-19 adalah virus baru yang awalnya muncul di Wuhan, China. Covid19 telah menjadi musibah bersama, termasuk Indonesia dan terkhusus provinsi Sumatera Selatan. Penelitian ini menghasilkan: 1) Pandemi Covid-19 berdampak negatif terhadap pertumbuhan ekonomi Provinsi Sumatera Selatan. Dimana pada tahun 2020 pertumbuhan ekonomi Provinsi Sumatera Selatan turun hingga -0,11 dari angka 5,96 di tahun 2019. 2) Covid-19 perpengaruh positif terhadap kemiskinan dimana pandemi covid-19 meningkatkan jumlah kemiskinan dan pengangguran, sehingga dapat diartikan bahwa pandemi ini berdampak negatif terhadap perekonomian.
\end{abstract}

Kata Kunci: Covid-19, Dampak Pandemi, Pertumbuhan Ekonomi

\begin{abstract}
Covid-19 is a new virus that originally appeared in Wuhan, China. Covid-19 has become a common disaster, including Indonesia and in particular the province of South Sumatra. This research resulted in: 1) The Covid-19 pandemic had a negative impact on the economic growth of South Sumatra Province. Where in 2020 the economic growth of South Sumatra Province fell to -0.11 from 5.96 in 2019. 2) Covid-19 has a positive effect on poverty where the Covid-19 pandemic increases the number of poverty and unemployment, so it can be interpreted that this pandemic negative impact on the economy.
\end{abstract}

Keywords: Covid-19, Impact of Pandemic, Economic Growth 


\section{PENDAHULUAN}

\section{Latar Belakang}

Corona virus yang muncul diakhir tahun 2019 telah menjadi fenomena dunia saat ini. Pandemi yang bermula dari kota Wuhan Cina telah menjalar keseluruh belahan dunia. Sebagamana di ketahuai Covid-19 adalah Dampak yang dihasilkan dari penyebaran wabah ini sangat besar terutama dalam perekonomian. Menurut data World Bank dalam Global Economic Prospect Januari 2021 menunjukkan bahwa perekonomian dunia mengalami penurunan. Pertumbuhan ekonomi nagara-negara dengan pendapatan tinggi tercatat $-5,4 \%$ pada tahun 2020, adapun pertumbuhan ekonomi Negara sedang berkembang juga mengalami penurunan hingga angka $-2.3 \%$ (IMF, 2021) termasuk didalamnya Indonesia.

Menurut data World Bank pertumbuhan ekonomi Indonesia tahun 2020 mengalami penurunan cukup drastis jika dibandingkan dengan pertumbuhan ekonomi Indonesia pada dua tahun terakhir yang berada pada angka 5,0\% sampai dengan 5,2\% (IMF, 2021). Saat ini semua negara sedang mengalami goncangan besar . banyak upaya dilakukan untuk mendapatkan satu set kebijakan terbaik untuk memperbaiki perekonomian ini. Ditambah lagi dengan beban fiscal yang semakin besar akibab wabah Covid-19 yang belum kunjung membaik. Diantara kebijkan pemerintah untuk merespon hal ini adalah munculnya Perpres No.72 tahun 2020 tentang perubahan postur APBN Indonesia (Antaranews, 8 February 2021).

Dalam peraturan ini presiden merubah kebijakan jumlah pengeluaran anggaran pada APBN 2020 menjadi Rp 2.739,16 T (Anataranews, 8 February 2021) dari angka sebelumnya sebesar Rp 2.540,4 (Direktorat Penyusanan Anggaran APBN, 2020) termasuk di dalamnya penambahan untuk biaya penangan covid-19.

Tidak terkecuali di Provinsi Sumatera selatan. Oleh sebab itu penulis berkeinginan intuk menganalisis dampak wabah Covid-19 terhadap perekonomian provinsi Sumatera Selatan secara lebih dalam. 


\section{Rumusan Masalah}

Untuk membuat sebuah kebijakan yang baik dalam penanganan covid-19 di bidang ekonomi, maka dipandang perlu untuk melihat bagaimana dampak yang dihasilkan oleh wabah ini terhadap Perekonomian dan Pembangunan Manusia (Tingkat Kemiskinan dan Pengangguran) di Provinsi Sumatera Selatan . Sehingga nantinya dapat memberikan solusi kebijakan yang tepat bagi pemerintah dalam memperbaiki keadaan perekonomian di Provinsi Sumatera Selatan. Dari hal di atas tersebut penulis membuat sebuah rumusan masalah yaitu:

1. Bagaimana dampak wabah Covid-19 Terhadap Kemiskinan di Provinsi Sumatera Selatan

2. Bagaimana dampak wabah Covid-19 terhadap Tingkap pengangguran di Provinsi Sumatera Selatan?

\section{Tujuan}

Melihat rumusan masalah di atas maka penulis membuat tujuan penelitian sebagai berikut:

1. Untuk mengetahui dampak wabah Covid-19 terhadap Tingkat Kemiskinan Provinsi Sumatera Selatan.

2. Untuk mengetahui dampak wabah covid-19 terhadap Tingkap Pengangguran di Provinsi Sumatera Selatan.

\section{Manfaat}

Manfaat yang diharapkan dapat dari penelitian ini adalah:

1. Kepada pemerintah: diaharapkan penelitian ini dapat menjadi tambahan referensi dalam pengambilan kebijakan yang tepat dalam menangani covid-19 dari sisi ekonomi.

2. Bagi Masyarakat: diharapkan penelitian ini dapat menjadi tambahan informasi berkaitan dengan keadaan ekonomi kota Lubuklinggau.

3. Bagi akademisi: penelitian ini diharapkan dapat menjadi tambahan refernsi dan dasar penelitian lanjutan yang dibutuhkan. 


\section{Landasan Teori}

\section{a. Covid-19}

Corona Virus 2019 (Covid-19) atau evere acute respiratory syndrome coronavirus 2 (SARS-CoV-2) adalah jenis baru dari corona virus yang menular ke manusia. Virus ini bisa menyerang siapa saja, seperti lansia (golongan usia lanjut), orang dewasa, anak-anak, dan bayi, termasuk ibu hamil dan $\underline{i b u}$ menyusui. Virus ini awalnya ditemukan di Wuhan Cina pada akhir tahun 2019, yang saat ini telah menyebar ke hampir semua Negara di dunia termasuk di Indonesia. Kasus terkonfirmasi di Indonesia mencapai 1,1 juta jiwa dengan jumlah kematian mencapai 32.167 jiwa (covid19.go.id 10-02-2021).

\section{b. Pertumbuhan Ekonomi}

Pertumbuhan ekonomi menurut Mujono (2005) secara sederhana diartikan sebagai kenaikan output total (PDB) dalam jangka panjang, tanpa memandang apakah kenaikan itu lebih kecil atau lebih besar dari laju pertumbuhan penduduk, serta diikuti oleh pertumbuhan struktur perekonomian ataupun tidak. Dalam hal ini yang digaris bawahi adalah prose, output perkapita dan jangka waktunya. Sehingga dalam jangka panjang akan menunjukkan perubahan perekonomian (Soleh, 2015).

Pertumbuhan ekonomi dapat diartikan juga sebagai perkembangan kegiatan dalam perekonomian yang menyebabkan barang dan jasa yang diproduksi dalam masyarakat bertambah dan kemakmuran masyarakat meningkat (Khakim et al., 2011).

\section{c. Teori kemiskinan}

Kemiskinan adalah salah satu permasalahan yang menjadi fokus pembahasan di semua negara berkembang, termasuk Indonesia. Berbagai konsep dan pemikiran untuk mengurangi tingkat kemiskinan sudah dilakukan hingga berbagai kebijakan diatur sedemikian rupa agar dapat menurunkan tingkat kemiskinan tersebut. Diantaranya Bantuan Langsung Tunai (BLT), PKH dll dilakukan oleh pemerintah dalam upaya mencegah dan mengurangi kemiskinan. 
Namun kebijakan- kebijakan tersebut seolah terpatahkan hanya dengan wabah Covid-19 yang terjadi sejak akhir 2019. Pengeluaran Negara membengkak, angka kemiskinan dan pengangguran menjadi berubah dan bertambah. Wabah ini telah menguras keringat dan pikiran pemerintah bahkan keuangan Negara. Dengan harapan berbagai permasahan sosial lain tidak berkembang dan menambah daftar pekerjaan pemerintah, baik pusat ataupun daerah.

\section{Pengangguran}

Badan Pusat Statistika (BPS) mendefinisikan Pengangguran sebagai orang yang mecari kerja, mempersiapkan usaha, merasa tidak mungkin mendapat pekerjaan dan orang yang sduah memiliki pekerjaan tetap namun belum bekerja. Diantara penyebab kemiskinan adalah kurangnya pendapatan. Jika seseorang memiliki pekerjaan namun tidak mencukupi maka mereka akan masuk ketegori orang miskin.

Maka tidak salah jika kita menyimpulkan diantara permasalahan yang menyebabkan kemiskinan dan pembangunan manusi tidak berkembang adalah rendahnya jumlah lapangan pekerjaan. Dengan rendahnya serapan tenaga kerja ini menyebabkan pengangguran yang berefek pada lemahnya perekonomian masyarakat. Dengan adanya pandemi saat ini menjadikan alasan yang tepat bagi sebgaian perusahaan untuk melakukan perampingan pegawai dan efisiansi, yang menyebabkan pemutusan hubungan kerja oleh perusahaan kepada sebagian orang.

Permasahalan ini memperburuk keadaan perekonomian daerah, dimana beban pengeluaran pemerintah semakin membesar untuk mencegak dampak negatif yang mungki muncul akibat tingginya angka pengangguran dan kemiskinan.

\section{Metodologi}

Metode yang digunakan dalam penelitian ini adalah metode Analisis deskriptif. Yang mana metode ini digunakan untuk menggambarkan sebuah objek dengan apa adanya. Selain itu metode ini juga bertujuan untuk menggambarkan objek penelitian dengan lebih sistematis. terhadap data yang tersaji dari Badan Pusat 
Statistik kota Lubuklinggau. Berkaitan dengan pertumbuhan ekonomi, kemiskinan dan pengangguran Provinsi Sumatera Selatan.

\section{PEMBAHASAN}

Covid-19 telam memberikan tekanan yang cukup besar bagi perekonomian Negara. BPS merilis data bahwa pada kuarta II tahun 2020 pertumbuhan ekonomi Indonesia mengalami penurunan hingga $-5,23 \%$. Angka ini turun dari kuartal sebelumnya yang hanya $2,97 \%$. Hal ini disebabkan diantaranya oleh pembatasan sosial yang dilakukan pemerintah untuk mencegah penukaran covid-19 dimasyarakat. Sehingga dengan adanya pembatasan sosial ini aktifitas ekonomi masyarakat menurun yang berimbas pada penurunan perekonomian.

Hal seupa juga terjadi diberbagai provinsi di Indonesia tak terkecuali provinsi Sumatera Selatan. Jumlah total masyarakat yang terkonfirmasi positif Covid-19 hingga 24 Maret 2021 mencapai 17.000 orang dan korban meninggal mencapai 825 orang (sumsel.inews.id). dengan tingginya jumlah kasus ini menyebabkan beberapa pemerintah daerah juga melakukan pebatasan sosial yang dampaknya dalah pada penurunan tingkat produktifitas dan perekonomian daerah. .

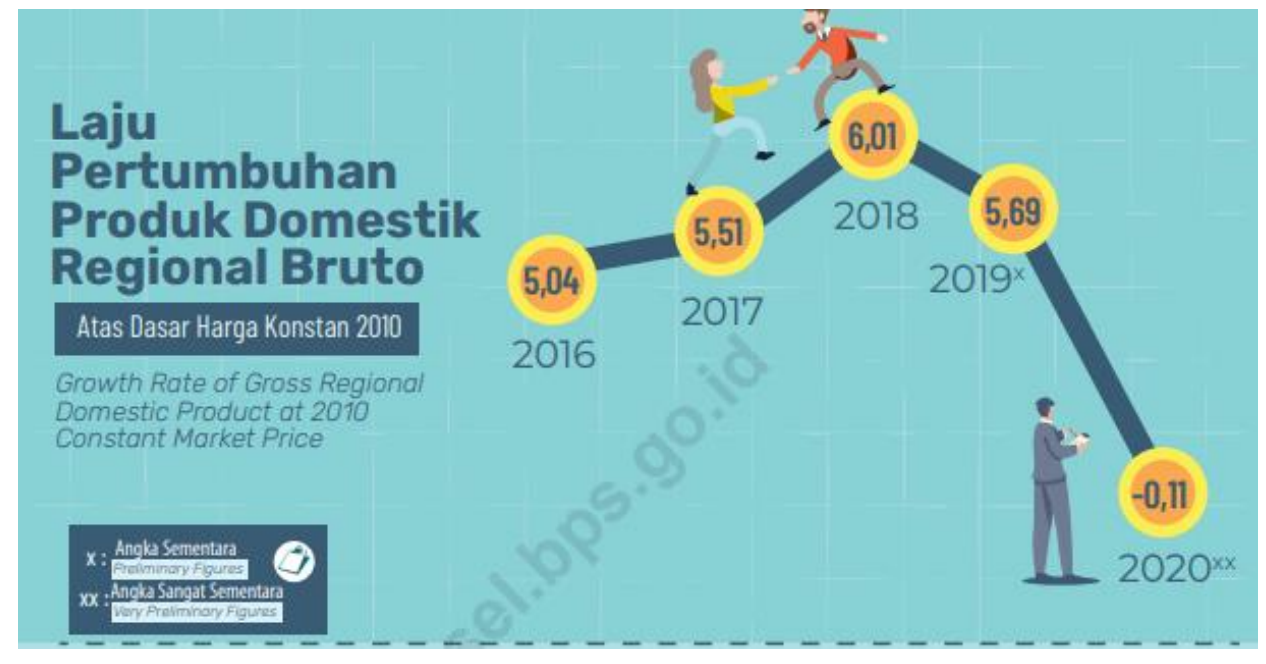

Gambar 1. Laju Pertumbuhan PDRB Sumatera Selatan By: Sumatera Selatan dalam Angka 2021 
Dari gambar di atas dapat kita lihat dari sisi pertumbuhan ekonomi provinsi Sumatera Selatan dari tahun 2016-2020 mengalami fluktuasi. Pertumbuhan Ekonomi tahun 2016 hingga 2018 Sumatera Selatan mengalami peningkatan hingga mencapai angka $6,01 \%$. Namun pada tahun setelahnya hingga 2020 mengalami penurunan yang cukup signifikan hingga mencapai angka $-0,11 \%$. Rendahnya pertumbuhan ekonomi ini menyebabkan masalah lanjutan pula bagi masyarakat. Diantaranya adalah Pemutusan Hubungan Kerja (PHK) yang dilakukan oleh beberapa perusahaan dikarenakan keadaan keuangan mereka yang memburuk. Selain itu bagi mereka yang bekerja di sektor informal terpaksa mengehentikan aktifitas kerja mereka karena aturan dan ancaman penyebaran pandemi ini.

Demikian ini selaran dengan hasil riset yang dilakukan oleh SMERU Research Institute (2020) berkaitan dengan "Mengantisipasi Potensi Dampak Krisis Akibat Pandemi COVID-19 terhadap Sektor Ketenagakerjaan". Dari riset ini didapati bahwa dalam sector ketenagakerjaan covid-19 menyebabkan peningkatan jumlah pengangguran terbuka.(Kompas.com11/8/20)

Statemen ini didukung dengan data yang disajikan oleh BPS terjadi peningkatan persentase jumlah pengangguran terbuka di Provinsi Sumatera Selatan.

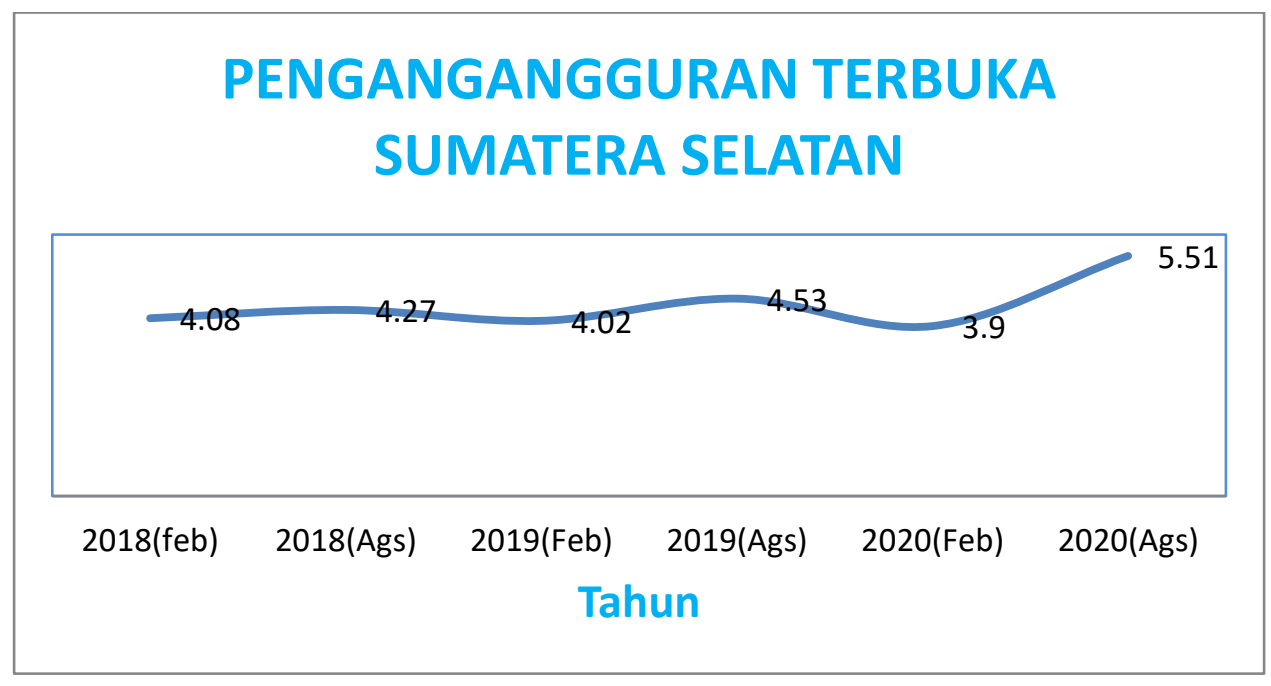


Gambar 2. Jumlah Pengangguran Terbuka SumSel

Data didapat dari : Sumatera Selatan dalam angka 2021

Kurva diatas menunjukkan jumlah pengangguran terbuka Sumsel dari tahun 2018 hingga 2020. Jumlah pengangguran mengalami Peningkata pada akhir 2020. Dimana hal ini terjadi setelah pandemic covid-19 masuk ke daerah. Pembatasan sosial yang diatur pemerintah telah menurunkan produktifitas pelaku usaha. Penurunan produktifitas ini mengakibatkan perubahan kebijakan pada masing masing perusahaan, diantaranya adalah efisiansi dan perampingan pegawai. Kebijakan ini berujung pada dirumahkannya sebagian pekerja hingga pemutusan hubungan kerja (PHK) bagi sebagian yang lain.

Pengangguran ini secara tidak langsung nantinya akan menyebabkan masalah baru bagi masyarakat. Diantaranya meningkatnya jumlah masyarakat miskin disebabkan hilangnya mata pencaharian sebagian masyarakat. Dan ini pun telah terlihat dari data yang di keluarkan oleh Badan Pusat Statisttika Provinsi Sumatera Selatan:

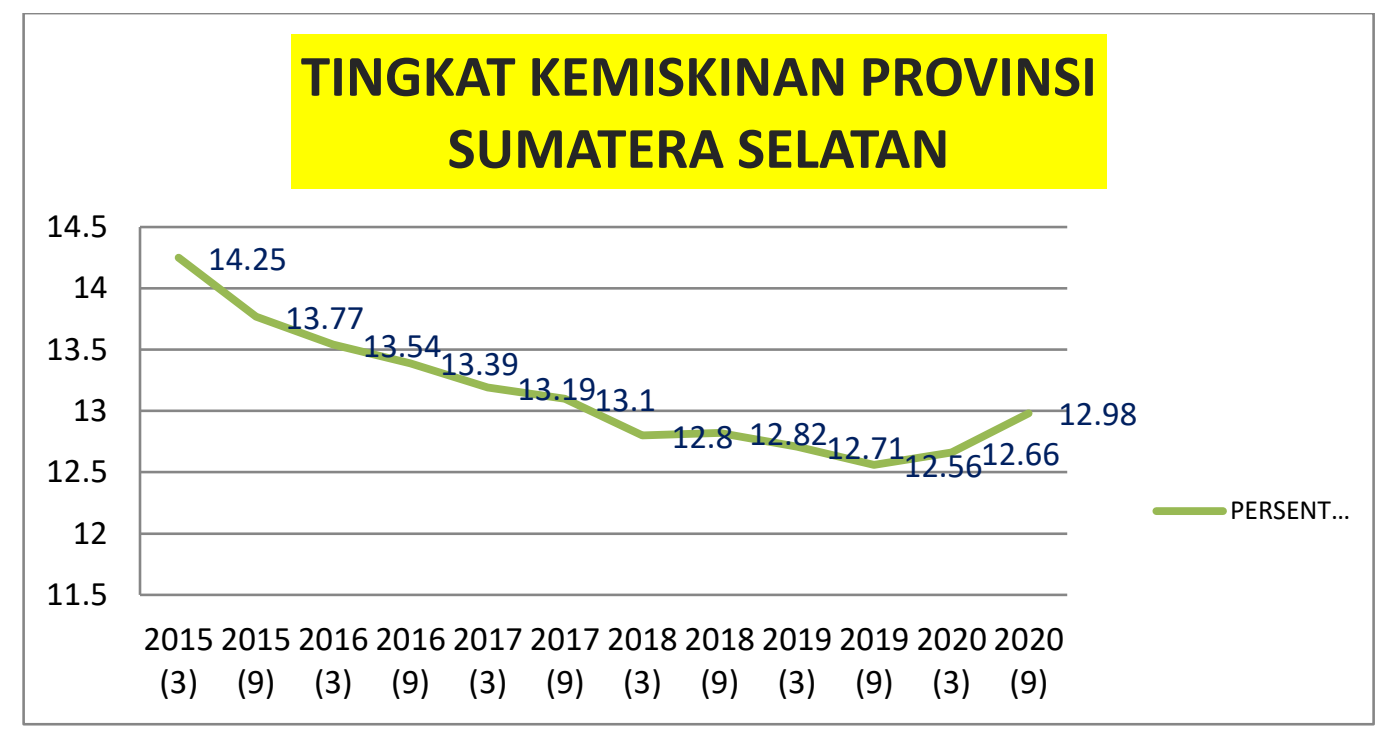

Gambar 3. Data Tingkat Kemiskinan Sumsel

*by: BPS Sumsel "Sumsel dalam Angka 2021” 
Pada tahun 2015 hingga akhir 2019 jumlah masyarakat miskin di provinsi Sumatera Selatan terus mengalami penurunan. Namun dapat kita lihat bahwa jumlah kemiskinan mengalami peningkatan sejak maret 2020 sebesar $0,10 \%$ lebih tinggi dari September 2019. Bersamaan dengan kemunculan virus corona di Indonesia jumlah masyarakat miskin di Provinsi Sumatera selatan pun meningkat hingga akhir 2020 sebesar 0,32\% dari jumlah sebelumnya.

\section{PENUTUP}

Pembahasan diatas memberikan kesimpulan bahwa Pandemi Covid-19 berdampak Negatif terhadap Pertumbuhan Ekonomi Sumatera Selatan, statemen ini di dasari oleh data pertumbuhan ekonomi Sumsel yang mengalami penurunan pada tahun 2020. Selain itu ditambah dengan data bahwa Pandemi Covid-19 berpengaruh Positif terhadap peningkatan pengangguran dan kemiskinan di provinsi Sumatera Selatan yang artinya berdampak negatif terhadap perekonomian.

\section{Daftar Pustaka}

BPS. 2021. Provinsi Sumatera Selatan dalam Angka 2021

Direktorat Penyusanan Anggaran APBN. (2020). Informasi APBN 2020.

Kementerian Keuangan R.I, 29.

https://www.antaranews.com. 2020. Pemerintah revisi APBN 2020, belanja negara jadi Rp2.739,16 triliun.(8 February 2021)

https://www.bbc.com/indonesia/dunia-53460946 (10/02/2021)

https://covid19.go.id/peta-sebaran-covid19(10/02/2021)

https://www.kompas.com/tren/read/2020/08/11/102500165/pandemi-covid-19-apa-

saja-dampak-pada-sektor-ketenagakerjaan-indonesia (06/04/2021)

https://sumsel.inews.id/24-03-2021

IMF, world bank. (2021). World Ekonomic Prospect.

Khakim, L., Hermawan, I., Solechan, A., \& PS, V. T. (2011). Potensi Fiskal 
Terhadap Pertumbuhan Ekonomi Dan Kesejahteraan Masyarakat. Jurnal Ekonomi Pembangunan: Kajian Masalah Ekonomi Dan Pembangunan, 12(2), 281. https://doi.org/10.23917/jep.v12i2.199

Soleh, A. (2015). Pertumbuhan Ekonomi Dan Kemiskinan Di Indonesia. EKOMBIS REVIEW: Jurnal Ilmiah Ekonomi Dan Bisnis, 2(2), 197-209. https://doi.org/10.37676/ekombis.v2i2.15

Sukirno, Sadono. 2011. Makroekonomi Teori Pengantar. Rajawali Pers. Jakarta.

Tambunan, Tulus. 2001. Perekonomian Indonesia: Teori dan Temuan Empiris. Ghalia Indonesia.

Jakarta.

Khakim, L., Hermawan, I., Solechan, A., \& PS, V. T. (2011). Potensi Fiskal Terhadap Pertumbuhan Ekonomi Dan Kesejahteraan Masyarakat. Jurnal Ekonomi Pembangunan: Kajian Masalah Ekonomi Dan Pembangunan, 12(2), 281. https://doi.org/10.23917/jep.v12i2.199

Soleh, A. (2015). Pertumbuhan Ekonomi Dan Kemiskinan Di Indonesia. EKOMBIS REVIEW: Jurnal Ilmiah Ekonomi Dan Bisnis, 2(2), 197209.https://doi.org/10.37676/ekombis.v2i2.15 